\title{
Chronological table
}

$13676 \mathrm{~J}$ an. Birth of Richard at Bordeaux

137721 J une Death of Edward III. Accession of Richard

138620 Nov. Commission of Government takes power

138720 Dec. Battle of Radcot Bridge

1388 Feb-J une 'Merciless' Parliament

1396 Richard marries I sabelle of France to seal 30-year truce

1397

J an-Feb. Parliament at Westminster

10-11 July. Arrest of Gloucester, Arunde and Warwick

5 Aug. Appeals presented against Gloucester, Arundel and Warwick at Nottingham

?8-9 Sept. Murder of Gloucester at Calais

17-30 Sept. 'Revenge' Parliament at Westminster

21 Sept. Trial and execution of the earl of Arunde

24 Sept. Announcement of Gloucester's death. Exile of Archbishop Arundel

28 Sept. Trial of the earl of Warwick

29 Sept. Creation of new dukes and earls

December. Outbreak of the Bolingbroke-M owbray dispute

1398

28-31 J an. Continuation of parliament at Shrewsbury

$30 \mathrm{~J}$ an: Bolingbroke accuses M owbray of treason

$23 \mathrm{Feb}$. Mowbray appears before Richard at Oswestry

1 March. Bagot pardoned for plotting against Gaunt

29 April. Bolingbroke and M owbray appear before Richard at Windsor

$20 \mathrm{July}$. Death of the earl of March at Kells, Ireland

27 July. French withdrawal of obedience from Pope Benedict XIII

August. French embassy to Richard concerning the Schism

16 Sept. Exile of Bolingbroke and Mowbray at Coventry

13 Oct. Bolingbroke leaves England for France 
25 Nov. Anglo-Papal concordat

1399

3 Feb. Death of J ohn of Gaunt

$18 \mathrm{M}$ arch. Richard seizes custody of the Lancastrian inheritance

April-May. Dukes of Burgundy and Berry leave Paris for the summer

1 J une Richard lands in I reland

17 J une Alliance between Bolingbroke and the duke of Orléans

28 J une York summons troops to met him at Ware, Hertfordshire

3 July. Sheriff of Sussex ordered to besiege Pevensey castle

?4 July. Bolingbroke lands at Ravenspur

12 July. Y ork musters his troops at Ware

?17 J uly. Salisbury and Creton sent from I reland to North Wales

?24 J uly. Richard lands at Milford Haven, South Wales

$27 \mathrm{July}$. Meeting of Y ork and Bolingbroke at Berkeley

29 July. Execution of Lescrope, Bussy and Green at Bristol

?31 July. Richard abandons his army near Carmarthen and sets out for Conway. His army disbands

?2 Aug. Northumberland appointed Warden of the West March of Scotland by Bolingbroke

5 Aug. Bolingbroke, at Shrewsbury, receives the surrender of Chester

8-9 Aug. Bolingbroke enters Chester

?15 Aug. Meeting of Richard and Northumberland at Conway

?16 Aug. Meeting of Richard and Bolingbroke at Flint

20 Aug. Richard and Bolingbroke leave Chester for London

2 Sept. Richard imprisoned in the Tower of London

21 Sept. Meeting of Council to discuss Crouchback legend'. Adam Usk visits Richard in the Tower

22 Sept. Death of Mowbray at Venice

28-29 Sept. Formal deputations visit Richard in the Tower to secure his abdication

30 Sept. Deposition of Richard II. Bolingbroke becomes King Henry IV

6 Oct. Parliament at Westminster

13 Oct. Coronation of Henry IV

18 Oct. Execution of J ohn Hall

23 Oct. Parliament agrees to Richard's imprisonment

29 Oct. Trial of the appellants of 1397 begins

3 Nov. Sentence passed on the appellants of 1397

19 Nov. Parliament dissolved 
?December. Richard moved to Pontefract castle

1400

4-13 J an. The ‘Epiphany Rising'

4J an. Henry flees from Windsor to London after being warned of the plot

$6 \mathrm{~J}$ an. Rebels arrive at Cirencester

$8 \mathrm{~J}$ an. Execution of Kent and Salisbury at Cirencester

?9 J an. Execution of Huntingdon at Pleshey

$13 \mathrm{~J}$ an. Execution of Despenser at Bristol

$29 \mathrm{~J}$ an. Rumours in France of Richard's death

?14 Feb. Death of Richard at Pontefract castle

17 Feb. Council orders Richard's body to be brought to London

6 March. Requiem mass for Richard at St Paul's, prior to his burial at King's Langley

1413 Death of Henry IV (20 March). Richard's body reinterred in Westminster abbey by Henry $\mathrm{V}$. 